Юлія Колос

ORCID: https://orcid.org/0000-0001-9931-3178

Майя Купар

ORCID: https://orcid.org/0000-0002-0016-4801

DOI 10.31558/1815-3070.2020.40.2.18

УДК [37.01] 316.776:371-024.87

\title{
ОРГАНІЗАЦІЯ СУБ'ЄКТ-СУБ'ЄКТНОЇ ВЗАЕМОДІЇ ПІД ЧАС ВИВЧЕННЯ ІНОЗЕМНОЇ МОВИ В УМОВАХ ДИСТАНЦІЙНОГО НАВЧАННЯ
}

\begin{abstract}
Описано основні переваги та труднощі дистанційного навчання, зокрема під час вивчення іноземних мов. Розглянуто види взаємодії за дистанційної форми організації навчання. Проаналізовано поняття суб 'єкт-суб 'єктної взаємодії, описано методи й передумови ї організачії під час вивчення іноземної мови у навчальному процесі вищого навчального закладу. Наведено приклади анкет для рефлексії викладача й студента.

Ключові слова: суб'єкт-суб'єктна взаємодія, дистаниійне навчання, комунікативний підхід, активне навчання.
\end{abstract}

Сьогодні людство зіткнулося з безпрецедентним викликом, а саме глобальною пандемією, спричиненою вірусом Covid-19, що докорінно змінює наш світогляд та спосіб життя. Чи не єдиною формою організації навчання за цих умов $\epsilon$ дистанційна, що здійснюється за посередництвом інформаційно-комунікаційних технологій. 3 іншого боку, незважаючи на пандемію, життя не зупинилося, процеси глобалізації та міжнародної комунікації тривають, їхні темпи дедалі пришвидшуються, тому високоякісна підготовка майбутніх фахівців до спілкування іноземними мовами є дуже важливою частиною їхньої професійної компетентності. Хоча дистанційне навчання має чимало безсумнівних переваг, у процесі його підготовки й реалізації виникає чимало тр уднощів, які можуть стати на заваді успішному завершенню курсу та досягненню цілей навчання. Сер ед них: відсутність прямого (неопосередкованого) спілкування між учасниками освітнього пр оцесу, труднощі, пов'язані з використанням комп'ютерних технологій, пасивність студентів та недостатня мотивація і саморегуляція навчальної діяльності. Подоланню зазначених та інших труднощів сприятиме на лагодження взаємодії між учасниками навчального пр оцесу на основах партнер ства, співробітництва та взаємного впливу, у якій кожен учасник був би активним та вмотивованим суб' єктом дії.

Проблеми дистанційного навчання висвітлювали Д. Бунік, С. Вайт, С. Гур іРозенбліт, Т. Маркус, М. Мур, К. Сван, А. Шер, С. Золотухін, І. Ібрагімов, О. Полат, Б. Шуневич, Г. Яценко та ін. Поняття суб 'єктності та суб' єкт-суб' єктної взаємодії між викладачем та студентами досліджували I. Бех, А. Бойко, Л. Пак, В. Сластьонін, С. Шехавцова та ін.

Метою статті є визначити переваги й недоліки дистанційної форми навчання, роль суб'єкт-суб' єктної взаємодії в пр оцесі дистанційного навчання інозем- 
ним мовам та фактори, що їй сприяють, дослідити інструменти для оцінювання взаємодії у процесі дистанційного навчання.

Об’єктом дослідження є дистанційна форма організації навчання у вищо му навчальному закладі, а предметом - взаємодія між учасниками навчального процесу під час вивчення іноземної мови за таких умов.

У процесі роботи використовувалися такі методи: теоретичний аналіз, синтез, індуктивні та дедуктивні методи, вивчення літератури, бесіди зі студентами.

Наукова новизна, теоретична і практична цінність дослідження полягають в тому, що його результати можуть бути використані під час організації дистанційного навчання у вищих навчальних закладах та у процесі розробки відкритих освітніх ресурсів.

До переваг дистанційного навчання можна зарахувати більш гнучкий розподіл часу, можливість студента суміщати навчання з роботою чи сімейними спр а вами, нівелювання комунікаційних бар'єрів з огляду на те, що спілкування з викладачем відбувається індивідуально, асинхронний у часі режим роботи дає простір для рефлексії й більш грунтовного засвоєння навчального матеріалу. Оскільки до всіх матеріалів дистанційного курсу є доступ, студент має мо жливість переглянути попередні теми, а через те, що спілкування з викладачем та іншими студентами відбувається у письмовій формі- перечитати повідомлення та відтворити у пам’яті хід думок у процесі вивчення певної теми. Окрім цього, дистанційне навчання сприяє підвищенню рівня індивідуалізації навчального пр оцесу, оскільки викладачу доводиться більше спілкуватися о кремо 3 ко жним студентом.

Низка дослідників погоджуються, що взаємодія під час дистанційного на вчання є ключовим фактором, який впливає не тільки на рівень засвоєння навчального матеріалу, а й на загальний рівень задоволення студента пр оцесом навчання та на успіх такого навчання загалом. Американський дослідник Майкл Мур виділяє три типи взаємодії у процесі дистанційного навчання: студентнавчальний матеріал, студент-викладач та студент-студент. До першого типу науковець зараховує процес розумової взаємодії студента 3 навчальними матеріалами, у результаті чого відбуваються зміни в розумінні речей, світогляді та когнітивних структурах свідомості студента. Це внутрішня дидактична розмова студента із самим собою в процесі опанування нового матеріалу. Навчальні матеріали можуть бути представлені у текстовому, аудіо- чи відеоформаті або бу ти реалізованими у комп’ ютерній програмі (M. Moore).

Варто зазначити, що оскільки дистанційне навчання студент здійснює знач ною мірою самостійно, то до навчального матеріалу висуваються високі в имо ги, зокрема до їхньої якості, обсягу, змісту та форми представлення. Щоб студент не втратив бажання вивчати курс, потрібно, щоб знання, які він здобу ває, були зорієнтовані на практику, щоб він чітко знав, де й коли вони йому знадобляться. Окрім цього, розбиття навчального матеріалу на невеликі за обсягом логічно структуровані фрагменти дає змогу звернути увагу на найважливіші питання та полегшити процес засвоєння знань. Взаємодія студента 3 навчальним матеріалом передбачає ознайомлення, написання наукової роботи, пр оходження інтерактивних тестів тощо. 
М. Мур зазначає, що функцією викладачів під час дистанційного навчання під час взаємодії студент-викладач є стимулювати та підтримувати інтерес студентів до навчання, сприяти їхній саморегуляції та самомотивації. Викладачі презентують знання або вміння чи моделюють певні відношення й цінності. Після цього вони організовують застосування студентами вивченого на практиці. Викладачі організовують оцінювання, щоб пересвідчитися, що студенти засвоїли знання, або щоб змінити стратегію викладання навчал ьного матеріалу. I врешті вони надають консультативну допомогу, підтримку та заохочують студентів (M. Moore).

Водночас надзвичайно важливим у дистанційному навчанні є отримання усіма сторонами повноцінного зворотного зв' язку один від одного для аналізу успішності та діагностики труднощів. Своєчасний зворотний зв' язок від інструктора (наприклад, відповіді на коментарі, повідомлення у форумі) позитивно впливають на навчання студентів. Заохочення зворотного зв' язку підвищує рівень задоволення курсом у студентів, а також допомагає підтримувати структурований темп навчання (Thurmond V. A., Wambach K.).

Взаємодія студент-студент - це третя форма взаємодії, що відбувається між двома й більше студентами за присутності викладача чи без ньо го. Ця надзвичайно цінна форма взаємодії дає можливість студентам не тільки опанувати м атеріал, але й розвинути якості лідера й навички роботи в команді. Варто зазначити, що робота студентів у групах не тільки допомагає усунути пр огалини в їхніх знаннях, а й має інше важливе значення - соціальна й емоційна підтримка (Haythornthwaite, 2001).

Прикладами взаємодії студент-студент є спільні сайти вікі й аудіоконференції, робота над проєктами, розбір конкретних прикладів у групах, взаємне навчання, дебати й дискусії, мозковий штурм, взаємне рецензування письмових робіт тощо. Взаємодія студент-студент забезпечує міцніші знання, створення спільноти, обмін ідеями й розвиток критичного мислення. Хан та Хілл (Han S. Y., Hill S. R.) вважають, що створення відчуття єднання $є$ надзвичайно важливим в інтернет-курсі, оскільки навчання розглядається не як передача знань від викладача до студента, а як процес конструювання пізнання, в якому кожен учасник робить свій внесок і отримує свої вигоди від ідей інших.

На думку науковців (Dan Bouhnik, Tali Marcus), до розробленої M. Мур ом системи взаємодії варто додати ще один аспект - взаємодію студента із системою, тобто з комп'ютерною технологією, що створює особливе навчальне середовище. Дослідники зауважують, що, впроваджуючи комп'ютерну технологію дистанційного навчання, треба переконатися, що вона буде зрозумілою і не створ юватиме додаткового бар'єра. У процесі дослідження (Dan Bouhnik, Tali Marcus) було з' ясовано, що якщо технічні проблеми, із якими стикаються студенти, не вирішувати відразу ж, рівень задоволеності студентів системою електр онного навчання знижується. Незрозумілий, незручний користувацький інтер фейс може справити негативний вплив на пошук відповідної інформації та взаємодію 3 навчальними матеріалами. У дослідженні (Vonderwell S., Zachariah S.) пр одемонстровано, що студенти, які часто почуваються дезорієнтованими, частіше відчувають когнітивне перевантаження й рідше беруть участь в онлайн-дискусіях. 
Основними недоліками дистанційного навчання, що впливають на якість комунікації в навчальному процесі, $є$ : брак прямої взаємодії між студентами та між студентами й викладачем (має місце лише взаємодія опосередкована), ві дчуття ізольованості, що виникає у студентів під час проходження курсу, втр ата невербальних сигналів, відсутність зорового контакту тощо. Сприятливі псих ологічні умови процесу навчання іноземній мові та подальша активізація діяльності студентів можуть бути досягнуті за рахунок стимулювання активності студента через використання різних типів завдань та використання суб' єктсуб'єктної моделі спілкування. Вважається, що така модель взаємодії фор мує у студентів готовність до прийняття аргументів співрозмовника, до взаємодії 3 ним; вона $€$ по суті діалогічною формою спілкування, у межах якої реалізується розвивальна стратегія (Ковалев 7).

Ознаками суб' єкт-суб'єктної моделі взаємодії під час спілкування є: рівність у стосунках між викладачем і студентом; зосередженість викладача на потр ебах студентів (перехід від процесу навчання, у центрі якого стоїть викладач, до навчання, у центрі якого знаходиться студент і його потреба у набутті необхідних знань, навичок, компетентностей); вільний обмін досвідом між викладачем i студентами; творчій підхід та експериментування тощо.

У процесі організації взаємодії зі студентами викладач повинен відбир ати найпродуктивніші методи навчання, що відбивають особливості взаємодії суб' єктів процесу навчання. До них належать, зокрема, методи активного навчання, комунікативний метод і метод пер еконання (Рендюк 33 ).

У деяких дослідженнях наводиться думка студентів про те, що якість інтер нет-взаємодії інструктора зі студентом іноді буває навіть кращою, ніж у тр ади ційному навчанні. Вона може проявлятися у формі неформальних повідомлень електронною поштою, у чатах, на форумах, у коментарях чи в більш формальному стилі записаних відео-й аудіоконфенцій (Золотухін).

Золотухін С. А. наголошує, що навіть дорослі студенти в пр оцесі дистанційного навчання потр ебують керівництва й схвалення з боку викладача. Повідомлення від викладача також зменшують психологічну дистанцію між студентами й посилюють відчуття соціальної присутності (Золотухін).

Важко переоцінити важливість встановлення партнерських стосунків та суб'єкт-суб' єктної взаємодії під час вивчення іноземних мов, де провідним методом $є$ комунікативний. Завдання викладача при цьому - організувати якомога ефективнішу взаємодію між студентами, створити умови, що спонукатимуть їх до рефлексії та обдумування вивченого матеріалу, всебічного його обговорення з одногрупниками. Для організації парної та групової р оботи викладач може, зокрема, організувати роботу над проєктами, мозкові штурми, обговорення реальних життєвих ситуацій. Прийдуть на допомогу й новітні комп'ютерні технології, зокрема, у месенджерах можна створити групи для чату в режимі реального часу, інструменти Гугл для спільної роботи над документами та презентаціями в режимі реального часу. Безкоштовні спеціалізовані онлайн-інструменти дають змогу, наприклад, завантажувати відео в мережу та залишати до нього коментарі з прив'язкою до певної часової позначки, створювати схематичні кар ти понять, записувати відео та аудіо тощо. 
Ключовими елементами для здійснення ефективного онлайн-навчання $\epsilon$ додавання до курсу таких видів діяльності, які: передбачають активне навчання; охоплюють різні види взаємодії; побудовані у такий спосіб, що наступний вид діяльності засновано на попередньому; передбачають надання зворотного зв'язку за результатами діяльності; надають можливість рефлексії студентам щодо вивченого матеріалу.

Щоб переконатися, що на занятті створено всі умови для активної участі сту дентів, їхньої позиції як суб' єкта навчального процесу, викладач може оцінити заняття за допомогою анкети, опублікованої у відкритому онлайн-курсі Універ ситету Індіани «Teaching online» («IU - Teaching Online»). Під час вибору методів навчальної діяльності викладачу пропонується відповісти на такі запитання:

1. Чи є завдання автентичним? Відповіді: так - 2 б., частково - 1 б., ні - 0 б.

2. Чи передбачає завдання можливість для активного навчання? Так - 1 б., ні -0 б.

3. Чи передбачає воно різні типи взаємодії? Так, усі три типи - 3 б., два типи -2 б., один тип -1 б., ні - 0 б.

4. Чи грунтується завдання на попередній роботі з курсу? Так-1 б., ні -0 б.

5. Чи дає цей вид діяльності можливість студентам отримати корисний зворотний зв' язок щодо їхньої роботи? Так, від викладача ТА одногрупників 2 б., так, від викладача АБО одногрупників - 1 б., ні - 0 б.

6. Чи заохочує завдання студентів до рефлексії щодо того, що вони вивчають, у який спосіб і для чого? Так - 1 бал, ні - 0 балів. Максимально - 10 балів.

Анкета студента для оцінювання ефективності взаємодії викладача й студента. Пропонувалося давати відповіді за 5-бальною шкалоювід «зовсім не погоджуюсь» до «цілком погоджуюсь» (Johnson, Aragon, Shaik, and Palma-Rivas):

1. Викладач заохочував мене брати активну участь в обговореннях.

2. Викладач надавав мені зворотний зв' язок щодо виконаних мною р обіт у вигляді коментарів.

3. Я взаємодіяв з викладачем у процесі обговорень під час вивчення курсу.

4. Викладач ставився до мене як до особистості.

5. Періодично викладач повідомляв мені про мої успіхи у вивченні курсу.

Анкета студента для оцінювання ефективності взаємодії студентів (Johnson, Aragon, Shaik, and Palma-Rivas):

1. Я ділився своїм досвідом навчання з іншими студентами.

2. Мені вдалося поспілкуватися 3 іншими студентами під час вивчення цього курсу. успішно.

3. Постійний контакт з одногрупниками допоміг мені закінчити курс

4. Серед студентів, які вивчали курс, панувала атмосфера єднання.

5. У цьому курсі мене заохочувати працювати в невеликих групах / командах.

Наведені анкети дають змогу викладачу оцінити ефективність розробленого ним дистанційного курсу й задають орієнтир для його удосконалення.

Дистанційне навчання $є$ перспективною формою організації навчального процесу, яка, на нашу думку, буде займати все міцніші позиції на ринку освітніх 
послуг. Проте для успішних результатів розробникам дистанційних кур сів та викладачам потрібно шукати ефективні комбінації прийомів та форм, повною мірою використовувати потенціал інформаційно-комунікаційних технологій, орієнтуватися на всі 4 типи взаємодії. Особливу увагу приділяти суб' єкт-суб'єктній взаємодії у режимі студент-викладач та студент-студент, забезпечувати своєчасний зворотний зв' язок, активне навчання, інтерактивність методів. Особливо це стосується навчання іноземним мовам, у якому комунікативна складова має бути наявна повсякчас. Перспективи подальших досліджень вбачаємо у р озробці методик дистанційного навчання іноземним мовам із комплексним та системним використанням інтерактивних методів навчання за посередництвом інформаційно-комунікаційних технологій.

\section{Література}

1. Золотухин С. А. Типы взаимодействия с обучающимися в компьютерно-опосредованном обучении. Современные исследования социальных проблем (электронный научный журнал), Modern Research of Social Problems, № 5 (25), 2013. URL: https://cyberleninka.ru/article/n/tipy-vzaimodeystviya-s-obuchayuschimisya-v-kompyuterno-oposredovannom-obuchenii (дата звернення: 08.10.2020).

2. Ковалев Г. А. Три парадигмы в психологии - три стратегии психологического воздействия. Общение и диалог в практике обучения, воспитания и психологической консультации: Сб. научных трудов. Москва, 1987. С. 4-16.

3. Рендюк С. П. Суб’єкт-суб'єктна дидактична взаємодія викладача і студентів у нав чальновиховному процесі технічних університетів. Імідж сучасного педагога, 2016. № 5. С. 32-34.

4. Bouhnik Dan, Marcus Tali. Interaction in distance-learning courses. Journal of the American Society for Information Science and Technology, 2006. № 57(3). P. 299-305.

5. Han S. Y., Hill S. R. Collaborate to learn, learn to collaborate: Examining the roles of context, community, and cognition in asynchronous discussion. Journal of Educational Computing Research, 2007. № 36(1). P. 89-123.

6. Haythornthwaite C. Exploring multiplexity: Social network structures in a computer-supported distance learning class. Information Society, 2001. № 17(3). P. 211-226.

7. IU - Teaching Online. Thinking About Learning Activities. URL https://canvas.ucdavis.edu/ courses/34528/assignments/3635?module_item_id=4976 (дата звернення: 08.10.2020).

8. Johnson S. D., Aragon S. R., Shaik N. \& Palma-Rivas N. Comparative analysis of learner satisfaction and learning outcomes in online and face-to-face learning environments. Journal of Interactive Learning Research, 2000. № 11(1). P. 29-49.

9. Moore M. G. Three types of interaction. The American Journal of Distance Education, 1989. № 3(2). P. 1-6.

10. Thurmond V. A., Wambach, K. Understanding Interactions in Distance Education: A Review of the Literature. International Journal of Instructional Technology and Distance Education, 2004. № 1 (1). URL: http://itdl.org/Journal/Jan_04/article02.htm (дата звернення: 08.10.2020).

11. Vonderwell S., \& Zachariah S. Factors that influence participation in online learning. Journal of Research on Technology in Education, 2005. № 38(2). P. 213-230.

\section{References}

1. Bouhnik Dan, Marcus Tali. Interaction in distance-learning courses. Journal of the American Society for Information Science and Technology, 2006. 57(3). P. 299-305. Print.

2. Han S. Y., Hill S. R. Collaborate to learn, learn to collaborate: Examining the roles of context, community, and cognition in asynchronous discussion. Journal of Educational Computing Research, 2007. 36(1). P. 89-123. Print. 
3. Haythornthwaite C. Exploring multiplexity: Social network structures in a computer-supported distance learning class. Information Society, 2001. 17(3). P. 211-226. Print.

4. IU - Teaching Online. Thinking About Learning Activities. Web. 08 Oct. 2020.

5. Johnson S. D., Aragon S. R., Shaik N. \& Palma-Rivas N. Comparative analysis of learner satisfaction and learning outcomes in online and face-to-face learning environments. Journal of Interactive Learning Research, 2000. 11(1), 29-49. Print.

6. Kovalev G. A. Tri paradigmy v psihologii - tri strategii psihologicheskogo vozdejstvija. (Tree paradigms in Psychology - three strategies of psychological influence). Obshhenie i dialog $v$ praktike obuchenija, vospitanija i psihologicheskoj konsul'tacii (Communication and dialog in practice of teaching, mentoring and psychological consulting). Moscow, 1987. 4-16. Print.

7. Moore M. G. Three types of interaction. The American Journal of Distance Education, 1989. 3(2). P. 1-6. Print.

8. Rendyuk S. P. Sub'yekt-sub'yektna dydaktychna vzayemodiya vykladacha i studentiv u navchal'no-vykhovnomu protsesi tekhnichnykh universytetiv (Subject-subject didactical interaction of teacher and student in technical universitys' education). Imidzh suchasnoho pedahoha (Modern pedagogue's image), 2016. (5). 32-34. Print.

9. Thurmond V. A., Wambach K. Understanding Interactions in Distance Education: A Review of the Literature. International Journal of Instructional Technology and Distance Education, 2004. 1(1). Web. 08 Oct. 2020.

10. Vonderwell S., \& Zachariah S. Factors that influence participation in online learning. Journal of Research on Technology in Education, 2005. 38(2). P. 213-230. Print.

11. Zolotukhin S. A. Tipy vzaimodejstvija s obuchajushhimisja v komp'juterno-oposredovannom obuchenii. (Forms of students interactionin computer-mediated education). Sovremennye issledovanija social'nyh problem (Modern Research of Social Problems). 2013. 5(25). Web. 08 Oct. 2020.

\section{ORGANIZATION OF SUBJECT-SUBJECT INTERACTION DURING FOREIGN LANGUAGE TEACHING IN THE CONTEXT OF DISTANCE LEARNING \\ Yuliia Kolos}

Department of General Linguistics and Foreign Languages, National University "Yuri Kondratyuk Poltava Polytechnic", Poltava, Ukraine.

\section{Maya Kupar}

Department of General Linguistics and Foreign Languages, National University "Yuri Kondratyuk Poltava Polytechnic", Poltava, Ukraine.

\section{Abstract}

\section{Background:}

During the COVID-19 associated quarantine period, distance learning became the only form of education which is carried out by means of information and communication technologies. Although distance learning has many undoubted advantages, there are a lot of difficulties for both teacher and student as well. The main problems are lack of motivation, absence of direct communication especially during foreign language teaching where it is vital, computer-associated problems etc.

Purpose: to determine the advantages and disadvantages of distance learning, the role of subject-subject interaction in the process of distance learning of foreign languages and the factors contributing to it, to analyze tools for assessing interaction and types of educational work in terms of their applicability.

Results: Distance learning is a promising form of educational process organization, which, in our opinion, will occupy an increasingly strong position in the market of educational services. However, to achieve successful results, distance courses developers and instructors should look for effective combinations of techniques and forms, make full use of the potential of information and communication technologies, focus on all 4 types of interaction. They also ought to pay special attention to subject-subject interaction in the mode of teacher-student and student-student relations, provide timely feedback, and utilize interactive learning methods. 
Discussion: We see prospects for further research in the development of methods of distance foreign languages teaching with a comprehensive and systematic use of interactive techniques by means of information and communication technologies.

Keywords: subject-subject interaction, distance learning, communicative approach, active learning.

Vitae. Yuliia Kolos is a Candidate of Pedagogical Sciences, Associate Professor, Associate Professor of Department of General Linguistics and Foreign Languages at National University "Yuri Kondratyuk Poltava Polytechnic". Her areas of research interest include formation of future translators' professional competence, use of computer technologies in foreign language teaching.

Correspondence: yulia.kolos@gmail.com

Vitae. Maya Kupar is a Lecturer of Department of General Linguistics and Foreign Languages at National University "Yuri Kondratyuk Poltava Polytechnic". Her areas of research interests include theory and practice of foreign language teaching, use of computer technologies in education.

Correspondence: maiia.kupar@gmail.com

Надійшла до редакціії 01 жовтня 2020 року. Рекомендована до друку 15 жовтня 2020 року. 